\title{
Impact of Sports Activities on Students Academic Achievement at Secondary School level in District Bannu KPK, Pakistan
}

\author{
Tanveer Ahmad ${ }^{1^{*}} \quad$ Nasir Ali $^{2} \quad$ Abdul Basit Khan $^{2} \quad$ Mumtaz $^{1} \quad$ Wali Ullah $^{2}$ \\ 1.Department of Education Qurtuba University of Science \& Information Technology Peshawar, KPK, Pakistan \\ 2.Institute of Education and Research, University of Science and Technology, Bannu, KPK, Pakistan
}

\begin{abstract}
The present study aims to find the impact of sports activities on students' academic achievements at secondary school level in district Bannu, KPK, Pakistan. The study was naturally descriptive. All the secondary schools' students of district Bannu were the population of the study. As a sample 500 students were randomly selected. A self-made questionnaire was used as data collection having five point likert scales. The final $9^{\text {th }}$ class board exam (DMCs) were the source from which the researcher obtained the academic achievements of the students which were recently issued by the Bannu Board. As descriptive statistic t-test was used. While Pearson coefficient correlation was used as inferential statistic. Both findings and conclusion indicates that sports activities and academic achievements of the secondary level school students have no significant relationship with each other.

Keywords: Sports, student, academic, achievements, secondary schools.
\end{abstract}

DOI: $10.7176 / \mathrm{JEP} / 10-33-11$

Publication date: November $30^{\text {th }} 2019$

\section{INTRODUCTION}

Sports are those activities which are requiring for balance personality. He further explained that the aim of education is not to discuss only few truthful information's regard students, but to keep them on the right way and become them well disciplined and creative minded. He also described that young students need moral, social, physical and intellectual growth, therefore every student is needed to give their attention on sports activities. He explained that sports is that activity which become the physically, morally, individually, mentally, developed(Katozai, 2004). Taking part in these activities very important for students at secondary school level, because these activities make the person well developed and creative minded (Emmer, 2010). Organizations may control the student's disruptive behaviors by arranging sports at school level. Educational organization may around different kinds of sports activities for the control of extra energy of the studio participated, due to which they can put them or the desirable activities. He observed that with the use of these activities, the stalk holders may punish the students by depriving them from sports activities, due to which they can do some disrupted activities in classroom. His behaviors of the students in the ground, they are playing. Further he explained that in the playground the teachers may positively change them, disruptive behaviors by also stated that due to sports activities we can identify the good and bad giving them instruction and good direct ion regarding good sports men ship and play with other(Cukurva, 2009).

Taking part in sports has great influence on students' academic achievement at secondary school level. He concluded that participation in sports can directly impact student's performance, because such activities make the individual healthier and patient. He compare that those students who were provide no time to participate in sports, their academic achievement was very weak and poor then those who participate in these activities. So he results that taking part in sports at secondary school level play very important roles in student's academic achievement (McNeely, et al, 2003). Take part in sports is very beneficial for school students, because it improve the academic performance of the students as well as their mental and physical growth. He stated that sports help in decreasing tension and anxiety. Further he described that those students who are mentally disturb, cannot perform well in any field of the life especially in learning process(Muniu, et al, 2009).

Admissions in sports organization or in other sports clubs provide better opportunity for improving examination success and student's social adjustment. Further he stated that those learners who were found regular in participation sports activities their academic performance was highly improved and fruit ful(Logan, et al, 2008).Participation $t$ in sports is very helpful than other activities after school time. He stated that there is very positive link between student's academic achievement and sports(Cooper, et al, 1999). Time should be specific for sports and other sports activities, because it is very destructive for students' performance to spend their valuable time in these academic all the day. He declared that spending most of the time in such activities decreases the students' ability, because they become tired and cannot study well(Eccles, 2003).Study in which they claimed that students negative views in school is due to lack take part in sports activities. They recommended that at secondary school level should provide proper arrangement of sports activities (Pascarella, et al, 1999).

From this study Young students' take part their physical and mental health bitterly. He also investigated that improvement were found in these young students who participated in sports at school level (Taras, 2005):Sports 
play very important role in the secondary school students' academic achievement in the United State (Griffith, 2007): Students of secondary school must to take part in sports activities becomes it is very essential to maintain physical health through sports (Mock, 2007). Beside academic achievement participate in sports also helpful in other activities in daily life (Coleman, 2006).Take part in sports activities are helpful in minimizing psychological depression problems (Clark, 2002).

Nowadays young students are not physically fit, this situation have increased the disability in students which is not good for their academic achievement becomes most of the time they cannot attend the classes on regular basis. They also stated that participation in sports program is very risky for students at school level (Sailis, 2001).The students' academic achievement at secondary school level is directly concerned with sports. Further he concluded that through sports and this like activities improves the students' educational motivation, self-esteem and other school level achievement (Ryska, 2003) Those resources that make a good sports it also becomes a students. They also stated that to remove the false conception and mind of the students, they may provide opportunities to participate in sports at secondary school and also out the school (Gay L, R, 1997).

It was found that those students who were always involved in sports activities, there academic achievement was very low as compared who sometimes or seldom participated .Further it was also concluded that long time participations in such program negatively impact students' academic achievement, because students may untouched with their schools, library, laboratory and teachers etc. (McHale, Crouter, and Tucker, 2001).

Taking part in sports activities are very useful after the completion of the secondary school certificate. It was also stated that at college and university level the students become more mature and they know better about the positive and negative influence of participation in sports activities. But at secondary school level, it is very important to avoid the students more the times from these activities, because their all attention goes towards these activities and their study remain incomplete and failed to acquire the highest grade at secondary school level (Cooper, Valentine, Nye, and Lindsay, 1999).

\section{RESEARCH METHODOLOGY}

\section{Research Design}

The main point of this research work was to investigate the impact of sport activities on students' academic achievement at secondary school level in district Bannu. Descriptive research design was used. Survey method was used for data collection.

\section{Population of the study}

Population of the study was comprised of all the secondary school students of district Bannu.

\section{Sample Size and Sampling Technique.}

As a sample total 500 respondents were taken from 20 secondary schools of district Bannu. From each school the researcher took 25 respondents as shown in the below table. According to L.R. Gay (1997) rule of thumb. The researcher selected the respondents through simple random sampling technique. 
Table No. 1 shows Selection of Respondent from 20 Secondary Schools Total respondents

\begin{tabular}{|c|c|c|}
\hline \multicolumn{3}{|c|}{ Total respondents } \\
\hline \multicolumn{3}{|c|}{500} \\
\hline $\begin{array}{l}\text { S. } \\
\text { No. }\end{array}$ & 20 Selected Secondary Schools & $\begin{array}{c}\text { Selected Respondents From } \\
\text { Each School }\end{array}$ \\
\hline 1 & Government Boys High School Azim Killa, Bannu & 25 \\
\hline 2 & Government Boys High School BAZAR AHMAD KHAN, Bannu & 25 \\
\hline 3 & Government Boys High School F.S.Mitha Khel, Bannu & 25 \\
\hline 4 & Government Boys High School Hakim Bharat, Bannu & 25 \\
\hline 5 & Government Boys High School Hakim Haved, Bannu & 25 \\
\hline 6 & Government Boys High School Ismail Khel, Bannu & 25 \\
\hline 7 & Govt. Boys High School Mama Khel Banochi, Bannu & 25 \\
\hline 8 & Government Boys High School Mandan, Bannu & 25 \\
\hline 9 & Government Boys High School Mira Khel, Bannu & 25 \\
\hline 10 & Government Boys High School No.1 BANNU, Bannu & 25 \\
\hline 11 & Government Boys High School No.2 bannu, Bannu & 25 \\
\hline 12 & Government Boys High School No.3 BANNU, Bannu & 25 \\
\hline 13 & Government Boys High School No.4 BANNU(C.M.S.), Bannu & 25 \\
\hline 14 & Government Boys High School Nurar, Bannu & 25 \\
\hline 15 & Government Boys High School Shabaz Azmat Khel, Bannu & 25 \\
\hline 16 & Government Boys Higher Secondary School Domel, Bannu & 25 \\
\hline 17 & Government Boys Higher Secondary School Ghoriwala, Bannu & 25 \\
\hline 18 & Government Boys Higher Secondary School Kakki, Bannu & 25 \\
\hline 19 & Government Boys Higher Secondary School Mamash Khel, Bannu & 25 \\
\hline 20 & Government Boys Higher Secondary School S.K.Bala, Bannu & 25 \\
\hline
\end{tabular}

\section{Analysis of data}

Descriptive statistic was used to determine the participation of students in sports activities. To know the impact of sport activities on student academic achievement, inferential statistic was used.

\section{Data collection instrument}

The data was collected with the help of self-made questionnaire having five points as always, usually, sometime, seldom and never. The researcher used these points to explore the level of secondary schools students' participation in sports activities. There were different facets in the questionnaire about deferent sports activities. The whole statements were 24 which was the result of pretest.

Scale in the Questionnaire

\begin{tabular}{|c|c|c|}
\hline S/NO & Version & Numerical \\
\hline 1 & Always & 1 \\
\hline 2 & Usually & 2 \\
\hline 3 & Some time & 3 \\
\hline 4 & Seldom & 4 \\
\hline 5 & Never & 5 \\
\hline
\end{tabular}

\section{Validity of the Tools}

For the validation of instrument the researcher requested to 10 experts in the field of education research and English language to refine the tool according to requirements, needs, and make it simple and understandable. In the light of fruitful suggestions the tool was finalized.

\section{Reliability of the Instruments}

The researcher administered the questionnaire among 30 respondents for the determination of reliability. The responses collected from the students were analyzed with the help of SPSS version ${ }^{22}$. The whole Cronbach alpha of the questionnaire was 0.86 as given below in the table.

Table 2: Cronbach Alpha Value of Each Facet in Tabular Form

\begin{tabular}{|c|c|c|}
\hline S/NO & VARIABLE & CRONBACH ALPHA VALUE \\
\hline 1 & Sports & 0.86 \\
\hline
\end{tabular}


Results and Discussion

Table 3: Mean score of sports activities $(\mathbf{N}=\mathbf{5 0 0})$

\begin{tabular}{|c|l|c|c|}
\hline S. No & \multicolumn{1}{|c|}{ Statement } & M & SD \\
\hline 1 & Play Hockey at school & 1.61 & 1.36 \\
\hline 2 & Take part in playing Cricket at school & 2.56 & 1.68 \\
\hline 3 & Participate in playing Volleyball at school & 1.95 & 1.49 \\
\hline 4 & Do well in playing Football at school & 2.08 & 1.53 \\
\hline 5 & Have fun of Badminton at school & 1.83 & 1.37 \\
\hline 6 & Good player of Basketball at school & 1.60 & 1.26 \\
\hline & Overall mean score & 1.93 & .82 \\
\hline
\end{tabular}

The mean value of students' participation in sports activities is 1.93 and stander deviation is .82. Table 4.1 Shows the mean score of the students participation in sports activities $\mathrm{M}=1.93$ and $\mathrm{SD}=.82$. The fall of mean score in rage of Seldom=1.51-2.50, which means that students seldom participate in sports activities.

Table.4 Correlation between co-curricular activities and academic achievement of students. $(\mathrm{N}=500)$

\begin{tabular}{|l|l|c|c|}
\hline S. NO & Variable & $\begin{array}{l}\text { Pearson } \\
\text { correlation }(\mathrm{r})\end{array}$ & Sig. (p) \\
\hline 1 & Sports activities and academic achievement of students & .02 & .57 \\
\hline
\end{tabular}

Table 4.6 presents the coefficient of correlation between sports activities and academic achievement of students $\mathrm{r}=.02$ and $\mathrm{p}$ value $=.57$ at 0.05 level of significance. The $\mathrm{p}$ value is greater than .05 , which means that there is no significant relation between sports activities and academic achievement of students.

Table 5 Shows Mean comparison of students who participate and who do not participate in sports activities. $(\mathrm{N}=\mathbf{5 0 0})$

\begin{tabular}{|c|c|c|c|c|c|c|}
\hline & Variable & No & M & SD & T & P \\
\hline \multirow{2}{*}{ Sports Activities } & Participate & 203 & 356.11 & 47.64 & & \\
\cline { 2 - 5 } & Not participate & 297 & 365.49 & 51.37 & & .03 \\
& & & & & \\
\hline
\end{tabular}

Table 4.7 shows that mean scores of the students who participate and who do not participate in sports activities are $356.11,365.49$ and SD.47.64, 51.37 respectively with a p value .03 and a t value 2.06 at 0.05 level of significance, the $\mathrm{p}$ values is less than .05 which means that there is a significant difference between the academic achievement of students who participate and who do not participate in sports activities. The difference is in the favor of those who do not participate in sports activities.

\section{Conclusions}

1. There is no impact of sports activities such as Hockey, Cricket, Volleyball, Football, Badminton and Basketball on the academic achievement of the students at secondary school level in district Bannu, KPK, Pakistan.

2. It was revealed from the study that secondary schools students in district Bannu KPK Pakistan seldom participate in sports activities.

3. Significant deference was found between the academic achievement of students who participate and who do not participates in sports activities. The difference is in the favor of non-participants.

\section{REFERENCES}

Clark, M. (2002). Student athletes with learning disabilities: a model for effectivesupports. College Student Journal, March,1-14.

Coleman, J. (2006). The adolescent society: James Coleman's still prescient insights.Education Next, Winter, 1-5.

Cooper, H., Valentine, J.C., Nye, B., \& Lindsay, J.J. Relationships between five after-school activities and academic achievement. Journal of Educational Psychology, 91, 369-378.(1999).

Cukurova, Teachers' Perceptions on Corporal Punishment as a Method of Discipline in Elementary Schools. The Journal of International Social Research. 2/8 (2009).

Eccles, J. Extracurricular activities and adolescent development. Journal of Social Issues, 59(4), 865-889.(2003).

Emmer, R. Band. New York, NY: Rosen Publishing Group (2010a).

Emmer, R. Cheerleading. New York, NY: Rosen Publishing Group(2010b).

Emmer, R. Chorus. New York, NY: Rosen Publishing Group.(2010c).

Gay L., R., (1997). Educational Research; Competencies for analysis and application. Florida international 
university.

Griffith, D. (2007). More scrutiny of high school student-athletes needed to ensure academics a priority. $N A S B E$, $1-3$.

Katozai, M. A. Preparation for the PCS screening Test of Senior English Teacher. University Publishers Shop \# 8-An Afghan Market, Qissa Khwani Peshawar (2004).

Logan, W. L, \& Scarborough, J. L. Connections through clubs: Collaboration and coordination of a school wide program.Professional School Counseling. 12(2), 157-161.(2008).

McHale, S.M., Crouter, A.C., \& Tucker, C,J. (2001). Free-time activities in middle childhood: Links with adjustment in early adolescence. Child Development. 72, 17641778.

McNeely, C. A., Nonnemaker J. M, \& Blum, R. W. Promoting school connectedness: evidence from the National Longitudinal Study of Adolescent Health. Journal of School Health; 72(4):136-146.(2003).

Mock, G. (2007). Student-athletes must make the grade in the classroom. DukeUniversity News and Communications, July 3,1-4.

Muniu, R. K. Sport's participation and examination-related stress among selected Kenyan secondary school students. Unpublished PhD Thesis, Kenyatta University, Nairobi, Kenya. (2009).

Pascarella, E. T., Truckenmiller, R., Nora, A., Terenzini, P. T. Cognitive impacts of intercollegiate athletic participation: Some further evidence. The Journal of Higher Education, 70(1), 1-26.(1999).

Ryska, T.A. (2003). Sport involvement and perceived scholastic competence in studentathletes:a multivariate analysis. International Sports Journal, winter, 155-173.

Ryska, T.A., \& Vestal, S. (2004). Effects of sport motivation on academic strategies andattitudes among high school student-athletes. North American Journal of Psychology, 6, 101-120.

Sailis, J.F., Conway, T.L., Prochaska, J.J., McKenzie, T.L. \& Brown, M. (2001). Theassociation of school environments with youth physical activity. AmericanJournal of Public Health, 4, 618-622.

Taras, H. (2005). Physical activity and student performance at school. Journal of SchoolHealth, 75(6), 214-218. 